\title{
Procreative and performative kinship among residents in Victorian caravan parks
}

\author{
Janice Newton
}

Federation University

\begin{abstract}
Recent senior anthropologists have heralded a new era where performative social and cultural kinship may eclipse procreational 'biological kinship' in contemporary western society. This article takes research on permanent residents in caravan parks as an extreme case that may act as an exemplar for future western contexts. Between 2003 and 2008, interviews with caravanpark managers, 50 interviews with park residents and short field stays at 17 outer Melbourne and rural Victorian caravan parks, provided multi-sited ethnographic material for analysis. I argue that contemporary contexts for relatedness give scope for creative development of social performative ties with 'ex' spouses and in-laws, friends and pets. 'Biological' kin and family with a material dimension remain central, however, and a response to family need or rupture is often the broadening of the procreative kin links between grandparent and grandchild and between siblings. Childhood institutionalisation and divorce in particular, contributed to pathways towards caravan park housing. Other kin-based motivations include finding safe accommodation for wives; providing housing for young adult males after injury and family divorce; and arranging for housing succession for children. Ideas of blood and folk biology demonstrate considerable resilience in contemporary kinship arrangements.
\end{abstract}

Keywords: contemporary kinship, caravan park residents, Australia, mobile homes, trailer parks

Senior figures in anthropology have recently revived interest in broad questions concerning the relevance of anthropology to an understanding of kinship in our contemporary world (Strathern 1992; Godelier 2011: 2; Sahlins 2013). Strathern tells us that kinship is what people do with the facts of nature but the future might see only the cultural dimension remaining (1992: 46). Godelier acknowledges that although western culture valorises the biological aspect of kinship relations, there are an increasing number of contexts where the absence of biology in the kin relation confirms the significance of social ties: step-parenting, gay parenting, and families created by reproductive technologies (Godelier 2011). Sahlins uses non-western ethnographic examples to illustrate the centrality of the social as opposed to the biological to an understanding of kinship. Following Durkheim, he sees kinship as a form of mutuality of beings, an intersubjective belonging where people's lives are joined and interdependent. Such kinship can be created by procreation or by performative action, but folk biology is the usual conceptual model (Sahlins 2013). 
Godelier makes an empirical suggestion. The polemical views of those who lament the death of the family and those who celebrate the imminent ability of individuals to 'live as they desire and feel' should be set aside so we can:

make a detailed inventory of actual situations and practices before making a judgment ... setting aside theoretical assumptions and listening to what people have to say about themselves or others, about their past and their present, and trying to confront discourse with actual practice. (2011: 8)

There are logical reasons for presuming that permanent residents in a caravan park might be a particularly interesting and extreme case through which to assess the current trajectories of family and kinship institutions, given the lack of security of tenure and the evidence of attenuated kin and family ties and family fracturing that appears to precipitate many moves to caravan parks. Taking permanent residents in caravan parks as an exemplary case study, the primary aim of this article is to reflect on what people have been saying and assess trends in performative and procreational kinship in Australian society.

I argue that kinship for permanent residents in caravan parks may indicate a future resurgence of contexts where the social aspect of kinship may be developed and perhaps, more importantly, where the procreational or 'biological' aspects may be broadened. In the diminution or absence of ties based on procreation, kinship could become almost anything: strengthened ties of nature with siblings, or social ties with former step-parents, former spouses, co-residents, or pets.

Secondly, I aim to establish links between kinship status and context, and housing pathways. I will provide evidence for links between particular family circumstances and housing pathways to caravan parks. Of specific note in relation to this study of caravan park accommodation are attempts to find safe accommodation for wives, providing for sons after injury and divorce, and arranging for housing succession for children.

To develop the argument, I initially discuss in more depth the work of Strathern, Godelier and Sahlins in relation to that of social theorists, sociologists of the family, and anthropologists looking at contemporary western kinship. After introducing the context of caravan park studies and this study in particular, I will give evidence from interviews to support the persistence of strong kin ties among some residents in contrast to evidence of extreme kinship chaos or deprivation for many others. The circumstances surrounding divorced men, step-relations, severe rifts with one or two family members, relations with 'exes', with siblings, with pets and with close friends allow us to assess the likely future of procreational and performative kinship and kinship pathways to caravan park housing.

\section{KINSHIP IN THE WESTERN WORLD}

In 1989, Marilyn Strathern gave a series of lectures that were published as After Nature: English Kinship in the Late Twentieth Century (1992). Strathern was not the first to look at the anthropology of western kinship. She followed, for example, the 
foundational work of David Schneider in American Kinship (1968) in which he foregrounded 'blood', 'law' and 'love' as central cultural concepts, but Strathern had begun to think through the new circumstances of the explosion of divorce, social engineering of children through in vitro fertilisation, surrogacy and so on, and the anthropomorphisation of pets. She claimed that the first two facts of English kinship were the individuality of persons and the diversity of families. Individualism created a formal kinship that was weak but which continued the persistence of strong private emotions (1992: 12).

Strathern states that in the past, kinship has been understood to mean what people have done with the facts of nature. For the modern era anthropologist, the facts of kinship have been simultaneously facts of nature and of culture and society. The future, however, could entail a world in which 'nature' is gone and only culture remains (Strathern 1992: 46).

Ideas of what is 'natural' are culturally refashioned over time. For example, McFarlane argued that the English desire for pets and gardens was a reproduction of ties with nature in a new context. From medieval times pets began to appear as substitutes for children, and by the late twentieth century children had became a unique form of 'superior pets' in a society with late marriage, low birth rate and isolated living units (Strathern 1992: 12).

In the last half-century moves towards gender equality and the right to choose partners freely in western societies have weakened the marriage tie but the bond between parent and child remains central. Godelier and Sahlins have highlighted the created contexts where performative aspects of a purely social kinship are dominant. For Godelier this is pre-eminently negotiation around the step-parent:

Children in recomposed families ... have a hard time finding their bearings and place in these new configurations of persons and ties, and first of all deciding what to call their new 'parents'. (2011: 8)

Sahlins acknowledges that procreation is one way of establishing kinship, or of knowing the meaning of participating in another's life, but love, nurture, living together and surviving trauma, for example, are other routes (2013: 29). Ethnographic examples from Melanesia and the Inuit in Greenland, for example, confirm that these other routes to kinship are not metaphorical facsimiles of true kinship, but 'real' kinship themselves. Anthropologists, with a few important exceptions, are historically more renowned for their understanding of non-western and preindustrial societies than for knowledge of contemporary western family and kin relations, as this has traditionally been the domain of sociology.

All scholars agree that marriage ties have weakened but not all scholars acknowledge the continuing strength of ties of filiation, albeit ties now scientifically provable and separable into fertilisation, gestation and parturition (Godelier 2011: 1; see also Strathern 1992). The significant forces towards change in western kinship arise out of the 'deeper current' of individualism and include the right to freely choose partners and the centrality of desire, love and sexuality; moves towards greater sexual 
equality; and the increasing valorisation of the child and childhood in the smaller family unit (Godelier 2011: 6). The family has been forced to evolve to deal with problems arising from the multiplication of divorce. Both children and adults have had to "'find new bearings" when thrust into new domestic living arrangements embracing quasi-kinship relations' with people unrelated by classical Western family ties. The father or mother's new affines have no 'blood' ties with children. They have a purely social tie 'but society expects them to behave towards children who are not their own like "real" parents ... and the children in turn behave towards these adults who care for them on a daily basis as though they were their "real" children' (Godelier 2011: 532).

According to Godelier, this new evolving principle is familiar to anthropologists:

Parents are not only or even necessarily those who made the children by uniting sexually. They are also, and sometimes primarily, the adults who feed them, bring them up and ensure their future. (2011: 533)

Legislation in Great Britain in 1989 began to ratify the new form of kinship by giving step-fathers power to act on issues concerning child supervision and education (Godelier 2011: 533). Reproductive technologies also bring in new contexts that are similar to matrilineal societies in the sense that the father may be genetically unrelated to the child but is nonetheless denoted as the person who loves, protects, takes responsibility, and gives material assistance. Genetic truth is less important for a child's identity than the adult who brought it up, protected it and loved it (2011: 537).

Sahlins reiterates some of Godelier's points in his passionate book by arguing that kinship is culture and not biology (2013: 2). In his view, kinship can contain 'mystical' or 'enigmatic' effects such as suffering in place of kin and notions of sins of the father descending on the son (2013: 3). Although kinship 'fashioned sociologically can be the same as kinship figured genealogically' (Sahlins 2013: 5), 'there is nothing inevitable about kinship or procreation'. Shared eating (in some cultures representing transubstantiation of ancestors), cumulative parental care, and remembering acts of compassion can create the same effects. Furthermore, this is not a result of negotiated choice and flexibility but a central part of the order or structure of the system (Sahlins 2013: 9-10).

Relatives are intrinsic to the sense of self, so kinship is about people who belong with one another and whose lives are 'joined and interdependent' (2013: 21-22). Carsten has demonstrated how kin live each other's lives and die each other's deaths (Sahlins 2013: 28). He argues that the 'distinctive quality of kinship, mutuality of existence, helps account for how procreation and performance may be alternative forms of it' (2013: 28). Relationships may be formulated in genealogical terms but the essential quality is intersubjective participation (2013: 72).

Western society may be obsessed with the biological, genetic and natural aspects of kinship, but the social character of kinship has become situationally vital in many contexts and there is debate about how effective it may be. As Godelier says (2011: 8), 
many children find it difficult to 'find their bearings and place in these new configurations of persons and ties'.

Unlike our senior anthropologists, social theorists do not, as a rule, consider kinship. When they do consider family rather than the lonely and precarious struggle of individuals in contemporary society (Beck 2000; Bauman 2001: 6, 24-25), they highlight the narrowing and altering functions of the family. They reiterate the points made by Strathern. Intimate and emotional aspects of the family predominate as preindustrial economic roles become less relevant (Lasch 1977; Giddens 1990; Bauman $2001,2003)$. However, as sociologists of the family testify, the contemporary quest for perfect marital mates and the emotional base of families are far less secure than economic scaffolds of the past, so family relationships are frail (Giddens 1993; Cheal 2002; Bauman 2003), and there are material consequences.

There are proven links 'between divorce and economic disadvantage' and divorced people in Britain, for example, are the most likely to lose owner occupancy of a home (Clapham 2005: 48-52; Simpson 1998: vii, 9, 29). Divorce is directly relevant to housing affordability, security and mobility, and thence to residence in caravan parks. A changing demographic structure with people living much longer and far fewer babies being born also creates a new social environment in which new social arrangements will evolve (Cheal 2002).

Most sociologists of the family draw their conclusions from national statistics, surveys, interviews and questionnaire data. The smaller empirical and behaviourist studies from Australia do not always reflect the broader brush strokes of the western social theorists, but they do give some insight into kinship understandings. They note the continuing centrality of family for many, ${ }^{1}$ the evolution of new economic ties with grandparents, the flow of material aid to adult children and the revival of links with families of origin, for example siblings, after divorce (Millward 1995; Gilding 1997; Batrouney and Stone 1998; Amato et al. 2007; Families Australia 2007; Stevenson and Wolfers 2007; Statham 2011). ${ }^{2}$

Such social processes reflect a persistence of procreational ties with a material or economic dimension. They support the conclusions made by anthropologist Maila Stivens in the 1980s concerning kinship and generational flows of material aid among middle class Australians (1985). In Stivens' view a 'modified extended family' operated, where the family of birth continued reciprocal relationships to aid younger adult couples to buy a house, to help baby sit and, basically, to help the household survive through crises. Mother/daughter bonds were strongest and sister/sister bonds very important in a system where 'blood' ties operated more strongly than in-law ties (Stivens 1985). ${ }^{3}$ While Stivens focused on a modified extended family and the continuing economic relevance of procreational kinship, a British anthropologist who has used ethnographic techniques and case studies to understand contemporary divorce highlights the scope for individual negotiation and performative kinship after divorce.

In Changing Families: An Ethnographic Approach to Divorce and Separation, Simpson (1998) argued that increasing divorce created a 'chaotic backwash of altered 
personal and family circumstances' that threatened ontological security. Flexible adaptation in a relationship with the 'ex', however, is an example of the potential for performative social kinship to come into play. Simpson claims that the category of the 'ex' joins blood and affinal kin in central significance (Simpson 1998: 33). The 'ex' embraces the network of people who are no longer officially kin after marriage dissolution: ex-husbands, ex-wives, ex-sons-in-law, ex-sisters-in-law, ex-fathers-in-law and so on. There is a 'complex disentangling and disaggregating of social relations' after divorce but we have a bilateral kin system with a lot of potential for building kin networks. After divorce (and re-partnering) people can select from 'a very wide set of potential kin' (Simpson 1998: 34-5). Although some of his case studies continued the small nuclear family mould with clear father roles for the substitute pater who displaced the genitor, others developed an 'Extending Family' model. One divorcee was 'exuberant' about post-divorce possibilities for expansion and extension of kindred (Simpson 1998: 46).

Recent Australian scholarship develops some of these ideas about individual agency and choice after divorce. Qwah (2008) highlights choice and connectedness as divorcees in Australia draw upon family networks to respond effectively to their new status and renegotiate relations with the families of their former spouses. ${ }^{4}$ The imbalance caused by the loss of one's own nuclear family can also lead to more contact with one's family of origin after a divorce (Qwah 2008: 8).

The literature thus brings anthropological insight to a biological discourse that contrasts with a kinship landscape, and this is seeing an explosion of contexts for social performative kinship to eclipse procreational 'biological' kinship. Smaller empirical sociological family studies, in contrast to the broad social theory on individualisation, note the evolution of new economic ties with grandparents, the flow of material aid to adult children and revival of links with families of origin after divorce, which all represent a persistence of procreational ties with a material dimension. Flexible adaptation to the 'ex', however, is an example of social kinship developing. Detailed in-depth recent studies of mainstream Australian kinship relations are largely absent. Permanent residents in caravan parks offer an extreme case that may serve as an exemplar for future contexts.

\section{STUDYING CARAVAN PARK COMMUNITIES}

In Australia, at the same time as trailer parks were becoming a significant part of the United States housing landscape in the 1970s, the phenomenon of the permanent resident in caravan parks was also becoming more visible. There was a decline in government commitment to the provision of public housing and sites formerly associated with leisure and good times became linked with a disadvantaged sector of society. Policy adjustments had to be made to set baseline standards of housing, site infrastructure and residential security. ${ }^{5}$

Arjun Appadurai's framework for looking at global cultural economy appears particularly apt for looking at residents in a caravan park. 'Perspective and situatedness' 
make a difference, and 'angles of vision' characterise 'scapes' of cultural flow. An ethnoscape is:

the landscape of persons who constitute the shifting world in which we live: tourists, immigrants, refugees, exiles, guests workers and other moving groups and persons. (1990: 297)

Stable communities and networks (which can be termed culturescapes) of kinship, birth, residence and so on still exist, but are cross threaded everywhere with ideas and realities of motion (Appadurai 1990: 297).

Ethnographic and anthropological studies of caravan park communities ${ }^{6}$ are relatively rare but present more of a culturescape than ethnoscape. A minor theme of positive assessment of park living for retirees in particular was documented in the United States as early as the 1950s by Hoyt (1954) and two decades later by Johnson (1972). In these studies, the older residents felt they were 'all in the same boat' and enjoyed the sociality, freedom, protection from unwanted elements, security and sense of belonging to their specialised trailer parks. Recent survey-based South Australian studies (Rogers et al. 2009; Bunce 2010) reiterate these themes in an Australian context (supporting some previous commentaries on parks in the eastern states). ${ }^{7}$

By far the major theme coming out of sociological studies in United States and Australia, however, has been that of social disadvantage. ${ }^{8}$ These studies have a social policy focus and look at aspects of living in caravan parks such as poor health and educational outcomes; struggling women, children and the disabled; and the effects of social stigma and disempowerment (e.g., Miller and Evko 1985; Hogarth et al. 1994; Muller and Martin 2001; Wensing et al. 2003; Chamberlain 2005; MacTavish and Salamon 2006; Notter et al. 2008; Kusenbach 2009; MacTavish 2009).

Despite the similarity of some themes of analysis, there are some differences between the North American and Australian situations. The proportion of trailer park homes among the rural poor is very significant in the US. It is up to 20 million and 7.1 per cent of all housing according to Aman and Yamal (2010), MacTavish (2009: 75-6) and Salmon and MacTavish (2006: 45, 50), and many of these are family parks with single women and children. Stigmatisation of permanent park residents is deeply entrenched in the US (Kusenbach 2009; MacTavish 2009). A strong caravanning and holiday culture among those with modest incomes who retire to a beach caravan park, the small and decreasing proportions living in caravan parks in Australia (2 per cent of the population. Australian Bureau of Statistics 4102.0 2000; Australian Bureau of Statistics 2049.02011$)^{9}$ and welfare efforts to keep children out of these situations, may be part of the explanation for the somewhat decreased stigma in Australia.

The research for this study was undertaken between 2003 and 2008. It drew on ten interviews of caravan park managers, 50 interviews with park residents and on two short periods of fieldwork during weekends of significance for sociality in the Melbourne calendar (The Australian Rules football Grand Final and the running of the Melbourne Cup horse race) as well as field notes from multiple visits to the 17 caravan 
parks involved. ${ }^{10}$ The aim was to present a multidimensional understanding of the lives of permanent residents as individuals and as part of a social group or community residing in a park village, with narrower research aims targeting concepts of belonging and community. The work can be viewed as a multi-sited ethnography in which I write about an ideal-type bounded culture from the point of view of a participantobserver, in an effort to discern social patterns and continuities - a form of 'latter day holism', according to George Marcus (Clifford and Marcus 1986; Falzon 2009). Anthropological insight was, I believe, facilitated by a holistic approach, the use of key informant managers, field notes, semi-structured interviews and return visits (see Godelier 2011: 528-9).

The interviews with the managers (six female, four male), taken as a whole, revealed an overview of variously-sized park communities (19-275) and various types of parks (some containing mainly male transient workers, others designed more for the retired, single mothers and so on). Most managers were part of a husband and wife team and were aged between 40 and 60 years.

Large outer urban parks resembled micro towns, with small avenues and streets, lined with manufactured cabins, units, vans and annexes. Neat gardens, lawns or sometimes concrete surrounded central ablution blocks, clotheslines, perhaps a swimming pool or community centre with a table tennis table and a television. Identity markers such as national flags, football or motorcar insignia, garden ornaments and gardens acted as a counterpoint to the grid-lined sameness of some parks, as well as to the stigma associated with such housing.

These environments might be considered akin to preindustrial living with the propinquity and close living of a village, albeit without the cross-cutting ties of economy, kinship, politics and religion of past ages. Vans and units have thin walls that enhance permeability to nature (and a vulnerability to its excesses in the form of flood, fire and storm), as well as allowing permeability to both greater social interaction and social intrusion. It requires 'give and take' to live in such a place.

There are rules about cars, noise, rubbish and much more, and although good management aims to 'keep out the riff raff, there are often small pockets of the park known as 'Drunks' Corner' or 'Druggies Street'. Alternatively, areas with the most elaborate manufactured cottages may be called 'Little Toorak'.

Rural parks are generally in picturesque areas associated (when drought free) with lakes and rivers or creeks, and with regular returning vacationers during holiday periods. The good outer urban parks may have views of bushland or wetland parks, established exotic or native trees or, for example, an aviary. Some residents augment their closeness to nature by feeding native birds and possums. The bad urban parks have boom gate entries, concrete and high fences.

Daily life is generally quite peaceful as contract workers are absent more than twelve hours a day and many residents stay in their own units with their hobbies or television to amuse them. Some of the retired, unemployed and those on disability pensions cluster in twos or threes and gather at times to chat, enjoy the sun, share a beer or a cup of coffee or to remove the garbage. Men, in particular, are often seen 
singly or in pairs making small modifications and improvements to their house and site. These changes, such as awnings, blinds, trellis partitions, small fences and gardens create more privacy and greater insulation from the weather, add beauty and establish difference. Banter and gossip is exchanged as people walk by to do laundry, take the garbage out or visit the park office.

Overall, 20 female and 30 male residents, aged 19-81 years, were interviewed, most of them aged between 50 and 80 and of Anglo/Australian origin. A third were married, a third divorced/separated, 18 per cent were single and 14 per cent widowed. The occupation profile of residents, while diverse, was weighted towards unskilled labouring. Most of the respondents did not complete high school.

About half of the residents interviewed had owned a house previously and most at the time of research owned their own unit or van and a car. A little less than half had lived in their current park for less than 5 years but a few had remained in the park more than 20 years.

\section{KINSHIP OF THE RESIDENTS INTERVIEWED}

Living in a caravan park is associated with severe social dislocation and constrained lives but more than half of the residents interviewed had positive family and kin relations, which was assessed in terms of housing location decisions being made based on proximity to kin, a broad or intense kin network, and sharing Christmas with family. The almost ubiquitous family photographs in homes indicated the centrality of the idea of family in most people's lives.

Residents chose to live close to ailing fathers, to children and grandchildren, and to siblings. A single man in his fifties chose his caravan park on the basis of proximity to his father, who was 'a bit wobbly' due to a heart problem, and a sister whom he saw more than weekly, by travelling twenty kilometres on a motorised bicycle. A long term European migrant was happier living in a park that was more accessible to her five adult children. Previously, when she had lived in a more rural area, she was concerned by the distance from her family. 'That was a bit of a problem. And I didn't like that, because I've got a lot of family'. Another mature woman had many relatives living in close proximity to the park.

Some residents had intense kinship interaction, such as daily telephone contact with daughters and frequent sleepovers for grandchildren. Others had broad, friendly, less frequent interaction with nearby relatives, siblings, and children. At Christmas time, almost all residents spent the day with extended family and, in one case, 17 family members gathered for a sit down Christmas dinner in the carport of a park resident couple.

Sometimes other family members and people who were 'like close kin' lived in the same park. One man had an adult daughter living in the same outer Melbourne park for a time but she had since acquired her own farm further north. Another mature man had a daughter and partner who lived in the same rural caravan park for 6 months after relocating from interstate. A woman in a satellite/rural park had close 
friends whose daughter was 'like a daughter to her' as well as a brother living in the same park. In a rural park a young woman and her partner lived next door to her parents. Another young man in this park called the mother 'Nan' because of the woman's long-term friendship with his mother.

Reciprocal aid given was also a behavioural indication of close and positive ties between kin and can be viewed as a form of social capital enabling a more satisfactory quality of life. A rural couple saw their daughter at least once a week, the frequency somewhat dependent on the daughter's need for babysitting. A rural woman's husband mowed his mother-in-law's 'bit of a lawn in her unit for her ... when it needs it'. A rural man's adult son visited weekly and helped build his father's annexe with glass and flywire and the two of them worked on 'doing up' an old car together. The grandson of a woman in her seventies built new stairs to her unit after visiting with his wife and newborn baby and considering the future safety of his ageing grandmother. Although she had not seen them for 3 years and had no immediate plans to do so, one south-eastern Asian migrant stayed in contact with her family of origin by telephone and sent money for her sick father's medication when needed.

Family members could be called upon for temporary accommodation during medical emergencies or, for example, when a resident was recovering from an operation. The most frequent interaction with family occurred for one elderly woman when her older, 91-year-old sister cared for her when she was released from hospital, but at other times the care was reciprocated and the sister living in a caravan park provided transport and shopping help to her 91-year-old sibling. Reciprocal aid in daily practical aspects of living was important, then, for a minority dependent on living in close proximity to family members and, indeed, two men were full-time carers for their wives.

Kin ties formed out of procreation and affinity were the basis for almost all of the relations described above and they often had a practical or material dimension to supplement their emotional core. Social, or fictive, kinship also appeared under the guise of the girl who was 'like a daughter' and the woman called 'Nan' because of a previous friendship. I consider now residents with minimal or chaotic kinship relations which may characterise dystopic future visions of western society.

\section{EVIDENCE OF FAMILY AND KINSHIP UNDER STRESS}

Orphanage and divorce pathways to park living, difficulties in defining the family, the number of sole men termed 'loners', and the frequency of ruptured ties with family members provide evidence for increasing individualisation and an institution under stress and address the secondary aim of this article, which is to establish links between particular family circumstances and housing pathways to caravan parks.

Loss of family and subsequent childhood institutionalisation as well as divorce figured strongly as pathways to caravan park living. Disrupted family life and diminished support systems occasioned by childhood institutionalisation or fostering could well have affected housing pathways. Five of the residents had spent time during their childhood in orphanages or foster homes. 
An injured nurse living in outer Melbourne was born in the mid-1950s to a family of six children:

We became wards of the state so it was a disjointed family situation.

Did you get fostered out?

No, I stayed at the orphanage from when I was seven till when I was seventeen. Six of us: four boys and two girls. R (sister) went by the way of being rambunctious, went to Winlaton (Youth Training Centre), and went down a different path. I stayed in the orphanage, the four boys were fostered by a family, and so we were totally divorced from the boys.

The woman had spent some time trying to live with her sister but it had not worked out; the biological kin tie proved inadequate for a permanent supportive relationship and the state had 'divorced' her from her brothers. The pathway to caravan park housing after divorce appeared even more direct and clear cut for men who moved out of a house they had purchased or were paying off.

Several caravan park managers said that the majority of applicants to their parks were males needing housing because of a relationship break up. There was an increasing number of enquiries for men 'thrown out of [the] nest', who ended up with practically nothing. 'They end up with a ute [utility vehicle], a van and that's about it' (field notes 26 September 2008). Managers reported that the park acted as a buffer zone, or 'holding bay' until they got themselves 'sorted out'. After his break up, one rural man 'just walked away' with the fridge and the car (field notes 19 June 2008). Four men had been married for as long as three decades and had either signed over homes or left their wives living in them.

Women, too, were left with fewer housing options when a house was sold after a divorce. A woman in her fifties left the violent father of her five children in their marital home, and she had been obliged to rent since then. Another similarly aged woman was married for only 5 years to the father of her two children, after which she had to rent a house and raise the children alone for 13 years.

Divorce and childhood institutionalisation are, then, linked to pathways to caravan park living. Defining family is difficult for some, given the disrupted and changing family life they have experienced. For several people the notion of relatedness was complex and obscure because of divorce, deaths, separations, and re-partnering. Difficulties in defining family indicate chaos but also provide insight for new forms of social kinship:

Were you born into a big family?

Um, well, I've got two older brothers, and that's it. But then dad got remarried and had three more kids, and had three step-kids.

Oh, right. So there's a fair bit of family.

So, yeah. There's a fair bit of us. And then my stepfather, he's got four boys.

Did your mum re-marry too? 
No. But I just classify. Like, he's always been a father figure to me. But, yeah. He's got four boys, now. They're classified as brothers. So ...

Your mum and step-dad have split up now, but do you still see them?

Yeah, Mum lives ... just up the street, but my step-dad, he lives in (interstate city).

So you've lost contact with him, then.

Yeah. But I speak to him every day, because I miss him a lot. Because he was more than a ... he was father to me ... My real father passed away about 5 years ago but I didn't see him that much, because he lived in (another interstate city). (Young mother, aged 20, rural caravan park)

This girl's family reflected the complex contemporary context of the kin landscape for young people who have been subject to changing parental and sibling relationships. The father who was most 'real' to her was not 'biological' and had three modifying descriptors: he was her ex, de facto, step-father. She had two brothers, three half siblings and seven step-siblings. She classified her ex de facto step-brothers as 'real' brothers. The step relationship (as European folktales and frequent media reports of child abuse attest) can also be brittle and fraught.

A rural man was not sure if he still had a relationship with his step-children as, after his only wife died after a very long marriage, there was little contact with her three children. He saw them between one and three times a year. When asked if he had children he answered, 'I haven't ... I have, but I haven't, if you know what I mean? ... She was a divorcee'.

Death and the fragility of bonds with step-children left a rural man in his forties alone. He was:

the only child on my father's side, but I think my step-brothers and sisters, there was about four of them.

Right. Through your mother?

Mother's previous marriage, yes.

You were really like an only child except for your step-brothers and sisters, was it?

Yes.

Do you still see that part of the family?

No.

No? So you actually don't have many family ties from that?

Oh no, no. I don't have any at all ... I'm the black sheep of the family. ... And Dad just after Mum died, Dad just ended up kicking out, once they were old enough, starting kicking out their ... half-sister, and ... two half-brothers. They ended up leaving and I was the only one there, and we couldn't cope, and then my grandparents moved in. 
Similarly, an elderly man in a satellite park saw his own children 'not too often' as two lived interstate and, when his de facto wife died, he eventually evicted his partner's two 'freeloading' adult sons, as well as two of her daughters and their boyfriends who were living in caravans on the property without paying rent or electricity. At the time of the interview, he was in a fractious relationship with his step-children over the ownership of the park unit and his right to continue to live in it. His relationship with his step-children was so poor that half of them were refusing to allow him to be buried next to their mother, for whom he continued to grieve strongly.

Death and separation failed to leave these two men with a supportive kin network, and 'biological' kin and spouses appeared much more important than step-relations did. 'Loners' or sole men in parks appear to support claims about the increasing individualisation of society.

A manager noted that some residents did not have family visiting. 'They are just loners'. I classed nine men as having negative family and kin ties on the basis of an absence of socially active 'blood' ties, geographical distance (made more potent due to lack of money) or because of family arguments. The person with the least number of kin ties was a single man with only one sister living interstate. 'It's a couple of years since I've been over there, and she certainly can't afford to come here'. Similarly, five other mature men had seriously attenuated family ties, sometimes spending Christmas alone in the caravan park.

Although there were some notable exceptions, interviews with other residents (and observations of managers) suggested that there might have been a relatively widespread pattern of broken or fragile ties with family members. As well as a number of widowed (7), single (11), divorced or separated residents (15), 22 residents (18 rural, 4 urban) mentioned that they no longer had contact with a particular daughter or son, or that they had drifted apart from a sibling (44 per cent of those interviewed).

Residents in caravan parks, therefore, provide substantial evidence of contemporary stress in the institutions of kinship and the family: changing family groups, isolated men, ruptured ties with close family members and divorced men and women, sometimes alone, impoverished and cast adrift from their former social milieu.

Indicators of the continued salience of procreational and performative kinship ties for material survival and social interaction can be described as cultural responses to a new kinship landscape. Where the ideal of individuality is strong and tensions arise over step-relations and changed relations with former in-laws, for example, there can be adaptation to new situations.

\section{PERFORMING KINSHIP IN NEW LANDSCAPES}

As stated, a number of residents had good relationships with their grandchildren who, at least when young, had visited or stayed over for holidays. An outer urban woman's grand-daughter was at university studying psychology. When exams finished she 
stayed in the park with her grandmother where she had her own room, as she was 'not fond of her mother's new partner.

Couples also negotiated a variety of living arrangements. Weaknesses in the marital tie were reconstructed into workable forms where ties of responsibility and some commitment remained. Each relationship was premised on the wife or girlfriend wanting some 'space' and rejecting some of the socially expected aspects of married life.

An active man of 60 had a relationship with a girlfriend living in the adjacent town but she had no wish to move in with him, preferring her independence and space:

My little woman friend ... Sometimes she comes here, I go there sometimes, so ... She wants her space and vice a versa. That's all right ... Second time around you can understand.

A well-liked park resident in a satellite town had been married for over 40 years but for a period he and his wife had separated. He was unemployed but his wife had work as a chef:

We rather split apart. And then we were sort of, we were just good friends for a good while. And we decided to try it again. Live together and that. We have it now, so she does her thing, and I do my thing. Like, if she wants to go out, she goes out.

Two-and-a-half years after his wife's death, a rural man married a woman who was, like him, in her late seventies. They moved to the park together but with her multiple health problems and lifestyle, they had set up individually in two separate units:

We moved up here together but then we found out it was too small for the two of us to live comfortably ... This is actually my wife's van. We're sort of separated because of her health. We've been married 4 years, separated four times in that time. We're just not compatible. I'm her carer and we're still married. I spend about seven hours a day with her. Seven days a week .

Although this man still felt married, he acknowledged that his wife wanted her freedom and, indeed, there were rumours that she had been unfaithful with another park resident. If some residents were freeing up aspects of conjugal ties, others were shoring up links with siblings or former in-laws.

Sisters or brothers were often important, particularly for those residents who were single or disconnected from their family of orientation (through marriage). A single older man's commitment to his two single brothers resulted in the loss of his home, but he continued to enjoy their company when they came to stay and went out for a meal or played cards. A divorcee became closer to his brother's children than to his own when he helped to raise his brother's seven children interstate after the brother died. Another divorcee had a close relationship with his sister and saw more of his sister's children than his own daughter, son, two granddaughters, grandson, and other family members, who lived interstate. A rural single man travelled around from sister to sister before settling in a caravan park. A rural divorcee did not see his own children but had two sisters in the adjacent town that he saw 'probably about once or twice a week'. 
Understanding of, and research on, the sibling tie among the broader Australian community is limited. In older age, after widowhood and for those who are divorced or remain single, the sibling tie appears to be potentially a significant form of relatedness, and this broadens out biological kinship. Understanding of the social kinship regarding relations with former partners and in-laws is also quite rudimentary.

Divorce and re-partnering release a whole array of new potential relationships (and, sometimes, problems). Friendships and new in-laws created through a partnership that subsequently dissolved do not themselves dissolve automatically when the marriage ends. The 'ex' is a category of kin still being negotiated by many people in western society. In this study there were examples of parents keeping in touch with an ex son-in-law and, as the young 20-year-old mother testified, the father who was most 'real' to her was, in fact, her ex, de facto, step-father.

A woman in her sixties helped her former son-in-law to find accommodation in a caravan park and visited him there. A rural couple also described mixed relations with former sons-in-law. They still got on well with their daughter's first exhusband who was with a new partner. Together they supported the grandson in 'Auskick' and so on. The relationship with the second 'ex' was not so good. (The daughter's second husband left and took everything with him, including a utility they had purchased for him and sheds and so forth from the property.) (Field notes 7 March 2008).

Three men had a friendly, or at least tolerant, relationship with ex-wives. To give information on how their son was faring, one rural man's 'ex' rang him up every now and then. Another rural man, after at least 10 years' separation from his wife, still had a visit every 2 or 3 months from his former partner and he had, at least, visited the threshold of her house. Twice divorced, one older outer Melbourne man communicated on friendly terms with his ex-wife and finally understood why she had left him. In recent years she had given him hand-crafted presents of cushion covers and a quilt, since he had been back to visit her:

Actually, she gave me this chair I'm sitting in now ... She said she didn't like it ... she said, 'Do you like it?' I said, 'It's beautiful, what about the cushions?' So she says, 'You can have them as well.' So, I said, 'Good on ya!' (laughs).

Although the main focus of this article is on family and kinship, a few short notes about friendship and pets (See Newton 2006, 2014) allow consideration of a future where kinship might be 'anything', created socially and performatively between humans - and even with animals.

Friends were important for general socialising, help when someone was ill, in transport and in building projects. A few examples of a wider pattern will suffice. A rural man said, 'If any of them have got a project on, we all sort of pitch in and help each other ... so, you know, it's good'. One retired man performed odd jobs for other permanent residents, even doing the shopping for one elderly man. A young student could also count on help for renovating projects: 
We like, help each other with ... There was one of the guys that used to live in there ... that was putting in an air conditioner, so we were all helping to put that in there ... I'm putting in one soon, so, we organised with some of the guys there to help me out, to just help lift.

A rural divorcee occasionally visited a nearby water hole with friends from the park and also met up with other men to play pool in the recreation centre:

Like, on a Friday night, see we have our pool night (in the park) ... Playing pool and that. A lot of us get together and play. Have supper. It's good.

Three neighbouring men got together every early evening for a type of 'happy hour':

We all meet here. We rotate of an evening but mostly sit on Sam's verandah. They talk about what work they've been doing (or not!).

A sole permanent resident at one park had almost no kin network but some very good friends with whom he could stay regularly, house sit and go out with whenever visiting Melbourne. He also had a little terrier dog as a companion.

Gilding (1997) and Strathern (1992) have written of how people include pets as real family members, which is rationalised in terms of 'experience of affection and togetherness' (Gilding 1997: 21). For some lone men, in particular, pets were central for these reasons.

A divorced male resident who had very cramped quarters inside an ageing van retrieved photos of himself with two beautiful Tibetan Spanish dogs to show me (field notes 29 July 2007). An elderly woman was obviously very fond of her pet cockatiel that flew freely around in her annexe for a time every day (field notes 4 September 2008). A woman in her thirties and her partner had little or no access to her children. They were able to keep two loved dogs in the park in a little fenced area and had a small shrine in their cabin to a deceased pet. New managers had decided a man of 30 with a permanent disability could not keep his beloved dog, so he chose to move. His attachment to the dog took precedence over his otherwise satisfactory housing arrangement. Shared love of an animal brought friendships. An outer Melbourne divorcee, when in his late sixties, befriended a young man in his thirties:

Did he like the cat too?

Yes, yes, he liked, that's why I liked him, because the cat took to him and vice versa. So, I knew he weren't cruel with animals and, no, that really clinched it. No, he's a nice fellow, bonzer lad.

The above adaptive responses to new socially constructed kinship landscapes are likely to be generally experienced in the west, but some other responses relate in particular to material responsibilities for kin and caravan park housing, and thus to the second aim of the article. The first response concerns attaining security for wives and the following two concern ensuring housing for adult children. 
Two men made efforts to install their wives in a secure environment to allow for their absence. When they moved to the park, one worker:

was away (working) fourteen or fifteen hours a day. I always felt that (my wife), even though I left early morning and got home late at night, that she was pretty secure.

When an elderly man sold the marital home and intended travelling around with his wife in a van, he discovered he had a terminal illness and made efforts to get them settled in a regional town caravan park before he died. He wanted somewhere where his wife would 'have people around her'. She had lived there for 15 years.

Two young men were set up in caravan parks by a parent or parents. A car accident 10 years earlier had left a young man with a disability and unable to work. His parents organised a caravan for him to live in at their old holidaying caravan park. They often brought their own caravan to the park to spend a weekend with him. Another young male student's statutory homelessness appeared to be precipitated by his parents' divorce. His parents had owned their own home and business and, after 2 or 3 years, with the divorce settlement, his mother was able to buy a house, but meanwhile he left home, aged sixteen. While he completed his schooling in a regional city, his father and sister had moved to Melbourne and his mother was travelling around Australia with a new partner. His mother bought his caravan and helped him set up in the park.

Perhaps the most significant aspect of families helping out, with implications for caravan park residence, was housing 'succession'. This related directly to a parent's sacrifice of their own home, or of some of its value, to ensure home security for a child. Two men in an outer urban park had owned good houses in which their daughters now lived. After he was widowed, a rural resident downsized to a caravan and gave his house to his step-children. A rural couple sold their home to allow the purchase of a secure home for their daughter and her children after a divorce:

Well, she was not (in) a very happy marriage, which ended up in a divorce, and she had four littlies. So, she's got a lovely home out there now.

A woman explained how she prioritised keeping the family together in their own home, but decided to sell when one daughter was absent most of the time at university and her second daughter and her grandchild, living with her, bickered continually:

I said, 'I'm going to sell the house'. And daughter said, 'Can I buy it?' And I said, 'If you can raise it?' So ...

Always a bit tricky then?

Yes, it is.

Yes. Was she able to get a bank loan then?

Yes. A bit short, which means I'm a bit short. But that's all right. As long as I live for another 10 years, I'll be all right. And I intend to do that (laughs).

When death and divorce rupture family ties and stable housing, caravan parks offer an option and, in the above cases, material aid flowed mainly along 'biological' kinship lines, but on one occasion also to step-children. 


\section{CONCLUSION}

Appadurai's ethnoscape dimension with the idea of mobility and shifting worlds appears to match the residence situation in contemporary caravan parks, particularly in terms of the relationship mobility that follows divorce and renegotiated marriages (Appadurai 1990: 297). Caravan parks epitomise mobility for tourists, mobile workers and people searching for a holding bay after dissolved marriages flow through them. In this article I have highlighted the resilience of a broadening, cognatic, procreative kinship, as well as the scope for performative, social kinship with step-parents and former affines, fictive kin, friends and pets. On balance, the silent majority of those permanent residents with good kin relations and the material, reciprocal aid passing between kin give an impression of a 'culturescape', with stable communities and networks. A large minority of residents also, perhaps, foretell the ethnoscape framework of the new global culture mooted by Appadurai (1990).

I began with the aim of assessing trends in performative and procreational kinship in Australian society by taking as a starting assumption that permanent residents in caravan parks represented an extreme edge where the individualising social forces outlined by Strathern (1992) and Godelier (2011) and many social theorists (eg Giddens 1990; Beck 2000; Bauman 2001) may have been more severe. Anthropological studies are significant for keeping kinship on the research agenda and for thinking theoretically about new structural formations and cultural ideologies. Although the residents interviewed provided no examples for two of Godelier's (2011) new contexts for social kinship (gay parenting and families formed by reproductive technology), they were able to reveal adaptations to new kinship landscapes where relationships and intersubjective belonging (Sahlins 2013) persisted with the category of 'ex', and the potential significance of co-residential friendships and pets as kin substitutes for sole householders.

The creatively charged relationship intersections that mark sources of social change in the contemporary kinship landscape appear to be the legally-buttressed child/step parent relation, where society requires a non-blood relative to take on the role of pater (or less often, the mater) and, secondly, the cluster of ex-relatives by marriage after a divorce. The evidence from this research, while revealing potentiality for a positive pater role, indicates the fragility of this role after the death of a mother and no grounds for the great optimism voiced by Simpson's divorced man who was 'exuberant' about post-divorce possibilities for expansion and extending kindred (Simpson 1998: 46). The network of ex-relatives by marriage are formally lapsed or dismembered affines, but they are sometimes socially maintained as real kin in Sahlins' terms. Any understanding of the contemporary kinship landscape must consider this new category of social kinship. Relations with ex-spouses are often continued economically as well as socially in some form or another and relations with the ex in-laws may be re-negotiated in spite of the rupture of the legal, affinal tie. However, in terms of activated, socially constructed kin, it appears more likely that 'biological', family kinship under stress will be broadened, so that grandparent and sibling relationships are functionally activated to compensate for lack of a parent or spouse, as predicted 
by Qwah (2008, see also Statham 2011). These changes may become structured patterns rather than evidence of individually negotiating agents in a fluid, mobile, kinship environment.

This article has also given evidence for links between particular family circumstances and housing pathways to caravan parks. Attempts to find safe accommodation for wives, providing for sons after injury and divorce, and arranging for housing succession for children are particularly notable. This information confirms the findings of earlier anthropological argument (Stivens 1985) and more recent sociological studies referred to above. In spite of the focus on ultimately fragile perfect partners and emotional intimacy, material, practical dimensions of kinship reciprocity persist, the filial tie remains mainly strong and aid often flows from the older to the younger generation. Friendships and pets become a form of social kinship that can offer alternate support when these ties are not strong. Kinship, or knowing the meaning of participating in another person's life (Sahlins 2013: 29), can be achieved through nurture, living and working together but ideas of blood and folk biology demonstrate considerable resilience.

Please send correspondence to Janice Newton: j.newton@federation.edu.au

\section{NOTES}

1 North American and British research shows many parallels. Almost all people feel the need for intimate human contact and current Canadian research suggests that, in spite of personal friendship networks, family-based ties are most important. Although women and the elderly appear to hold to these ties most strongly, Scott claims that 'the importance of family events crosses gender and generational boundaries' (Cheal 2002: 37). We feel close to family members and we are expected to feel close to them. We try to put family first. Many people, particularly when they do not trust outsiders, like to keep things within the family, and most prefer to be helped by a close relative when ill or incapacitated (Cheal 2002: 36-37). Clapham (2005), an exponent of a pathways approach to housing, agrees that increased risk in contemporary society has by no means obliterated family ties, nor has it seen the diminished significance of family discourse. Most people in Britain are more family-than friend-centred and most people attempt to keep up long distance kinship through visiting and telecommunication. 'Despite the number of older people living alone, their personal networks are dominated by family links' (Clapham 2005: 43).

2 Some American research also notes the economic aspects of marriages. Empirical studies confirm that marriage is seen as voluntaristic, a choice among alternatives but one that does provide economic benefits such as risk pooling and joint consumption of public goods and leisure (Amato et al. 2007; Stevenson and Wolfers 2007).

3 Stivens' findings are supported by sociological scholarship from the 1990s by Batrouney and Stone (1998), Gilding (1997) and Millward (1995).

4 As Ambert (1988) also found in Canada, much depends on the quality of relations during the marriage and the desire to continue relations between children and grandparents.

5 Legislation in Victoria, Australia has had to recognise that parks for holidaymakers were, by the 1980s, becoming permanent homes for a minority. The Building Act of 1993 Part 12A 
(Victorian Consolidated Acts 2012) does not apply to movable dwellings. The Governor in Council regulates land use, design and construction standards, health and safety features etc. (Section 514). The Residential Tenancies Act (Part 4 Caravan Parks and Moveable Dwellings Residency Rights and Duties) has evolved continually to address rights and duties of owners and residents; the latter are defined as people who occupy for 60 consecutive days a caravan park site as a main residence. Residents own or rent a van or unit and rent the site on which it is placed. They are responsible for their own electricity, gas and water when it is metered (Section 162) and cannot 'interfere in the privacy and peace and quiet of other occupants' (Section 170). Owners have to make repairs, provide 24-hour access to cars and facilities, keep the park clean and observe limits on access to both occupied and abandoned vans (Sections 173, 174, 199, 359). Residents have the right to appeal to a Tribunal on some matters. If a resident fails to pay rent or behave appropriately or a rented van is to be sold, they can be given 60 days' notice to leave. If a caravan park is being converted to another use, residents must be given 6 months' notice (Section 311 Residential Tenancies Act 2010). When vans are old and weathered their mobility is limited. Notice that a park is to be sold for other use effectively makes many residents homeless.

6 There are some studies of the mobile population that passes through the communities, such as Counts and Counts 2001. There is also a fascinating history of the technological and geographic history of the van to mobile home in Hart et al. 2002.

7 Positive assessments are phrased in terms of lifestyle choice, sense of community and sometimes with sentimental attachment to former holiday venues. See Bunce (2007, 2010), Connor and Ferns (2002), Elliot (1994), Geggie (1994) and Greenhalgh and Connor (2003). See also Aman and Yamal (2010) and Margonelli (2013) on the benefits of caravan parks for ageing baby boomers in Pennsylvania and California.

8 British studies are sparse but are generally sociological and fit with the disadvantage discourse, for example, Zenner and Allison 2010. However, Allen (2000) acknowledged that staying in a caravan home could, in the right circumstances, offer more ontological security and thus better health than being moved on.

9 Of 54,685 people (non-tourists) who spent census night in a permanent caravan, ( 0.02 or $2 \%$ of the population) the Bureau, optimistically, argued only 12,963 were marginally housed and at risk of homelessness. They excluded those owning or buying caravans (30,192), with access to full time jobs (6751), with an income of more than $\$ 2000$ a week, with three bedrooms in their residence, and those who appeared to have alternative accommodation or enough money to rent elsewhere. Australian Bureau of Statistics 2011.

10 The research was aided by small grants through the School of Behavioural and Social Sciences and Humanities at the University of Ballarat, and the aid of Research Assistant Dr Brian Morris. The first phase, titled 'Urban fringe caravan parks: Indicators of housing shortage and social change', took place in 2003-4 and involved interviewing ten caravan park managers from outer Melbourne caravan park communities (See Newton 2005, 2006). The second phase, titled 'Permanent residents in caravan parks: Aspects of belonging', began in 2006 (University of Ballarat Ethics approval B06-127) and extended the research to twelve outer urban permanent residents, in an effort to gain a more valid insider perspective (see Newton 2008). In 2007-8, this phase was extended to rural and regional areas and another 38 residents were interviewed. Interviews were from 40 minutes to 70 minutes' duration. They were transcribed and analysed thematically using NVivo software. The Grand Final and Melbourne Cup fieldwork weekends took place at two outer urban parks. At least 20 parks were contacted or visited where no interviews were organised. Access to residents was largely dependent on managers cooperating with the research. 


\section{REFERENCES}

Allen, C. 2000 On the 'physiological dope' problematic in housing and illness research: Towards a critical realism of home and health, Housing, Theory and Society 17: 49-67.

Aman, D., B. Yamal. 2010 Home sweet mobile home? Benefits and challenges of mobile home ownership in rural Pennsylvania, Applied Geography 30: 84-95.

Amato, P., A. Booth, D. Johnson, S. Rogers. 2007 Alone Together: How Marriage in America is Changing. Cambridge, MA: Harvard University Press.

Ambert, A.-M. 1988 Relationships with former in-laws after divorce: A research note, Journal of Marriage and the Family 50(3): 679-86.

Appadurai, A. 1990 Disjuncture and difference in the global cultural economy, Theory Culture Society 7: 295-310.

Australian Bureau of Statistics. 2000 4102.0 Social Trends. Canberra: Australian Bureau of Statistics.

Australian Bureau of Statistics. 20112049.0 Census of Population and Housing: Estimating Homelessness. Canberra: Australian Bureau of Statistics.

Batrouney, T., W. Stone. 1998 Cultural diversity and family exchanges, Family Matters 51: 13-20.

Bauman, Z. 2001 The Individualized Society. Cambridge: Polity Press.

Bauman, Z. 2003 Liquid Love: On the Frailty of Human Bonds. Cambridge: Polity Press.

Beck, U. 2000 The Brave New World of Work. Cambridge: Polity Press.

Bunce, D. 2007 Relocatable homes: low cost housing in a suburban caravan park. Paper delivered at the 2nd National Housing Conference, University of Queensland, Brisbane, June <http://www.uq.edu.au/housingconference2007/index.htm-l?page $=57032>$, accessed 4 June 2008.

Bunce, D. 2010 Relocatable homes: Medieval tenure in the 21st century?, Urban Policy and Research 28(3): 277-92.

Chamberlain, C. 2005 Marginal residents of caravan parks, Caravan Parks...Watch This Space, Parity 18(5): $1-6$.

Cheal, D. 2002 Sociology of Family Life. New York: Palgrave.

Clapham, D. 2005 The Meaning of Housing: A Pathways Approach. Bristol: Policy Press.

Clifford, J., G. Marcus. 1986 Writing Culture: The Poetics and Politics of Ethnography. Berkeley: University of California Press.

Connor, J., S. Ferns. 2002 No Place for Home. The Loss of Permanent Accommodation on NSW Residential Parks. Sydney: NSW Park and Village Service, Combined Pensioners Superannuation Association of NSW.

Counts, D., D. Counts. 2001 Over the Next Hill: An Ethnography of RV-ing seniors in North America. Peterview, ON: Broadview Press.

Elliot, R. 1994 Location and planning of manufactured housing estates, in (ed.) J. P. Lea Manufactured Housing Estates in Australia. Sydney: Ian Buchan Fell Research Centre, University of Sydney, pp. 29-38.

Falzon, M. A. 2009 Multi-Sited Ethnography: Theory, Praxis and Locality in Contemporary Research. Farnham: Ashgate.

Families Australia. 2007 Grand Parenting: Present and Future: Report for Families Issues Series $2<$ http:// www.familiesaustralia.org.au/publications/index.htm>, accessed 11 October 2012.

Geggie, J. 1994 The main differences between caravan parks and MHEs are the design criteria and potential for community, in (ed.) J. P. Lea Manufactured Housing Estates in Australia. Sydney: Ian Buchan Fell Research Centre, University of Sydney, pp. 25-8.

Giddens, A. 1990 The Consequences of Modernity. Stanford: Stanford University Press.

Giddens, A. 1993 The Transformation of Intimacy: Love, Sexuality and Eroticism in Modern Societies. Cambridge: Polity.

Gilding, M. 1997 Australian Families: A Comparative Perspective. Melbourne: Addison Wesley Longman.

Godelier, M. 2011 The Metamorphoses of Kinship. London: Verso Books.

Greenhalgh, E., J. Connor. 2003 No place for home. Residential park decline and older people. Paper presented at 'Beyond the Divide', the Third National Conference of the Australian Federation of Homelessness Organisations, Brisbane, April, 2003.

Hart, J. F., M. Rhodes and J. Morgan. 2002 The Unknown World of the Mobile Home. Baltimore: The John Hopkins University Press.

Hogarth, D., J. Geggie and G. Eddy. 1994 When home is a caravan park, Children Australia 19(3): 4-8. 
Hoyt, G. 1954 The life of the retired in a trailer park, American Journal of Sociology 59(4): 361-70.

Johnson, S. 1972 Idle Haven: Community Building Among the Working Class Retired. Berkeley: University of California Press.

Kusenbach, M. 2009 Salvaging decency: Mobile home residents' strategies of managing the stigma of 'trailer' living, Qualitative Sociology 32(4): 399-428.

Lasch, C. 1977 Haven in a Heartless World: The Family Besieged. New York: Basic Books.

MacTavish, K. 2009 The wrong side of the tracks: Social inequality and mobile park residence, Community Development 38(1): 74-91.

MacTavish, K., S. Salamon 2006 Pathways of youth development in a rural trailer park, Family Relations 55 (April): 163-74.

Margonelli, L. 2013 How the trailer home could save us all, Pacific Standard May-June <http://www.psmag.com/health/how-the-trailer-park-could-save-us-all-55137>, accessed 10 April 2013.

Miller, S. and B. Evko 1985 An ethnographic study of the influence of a mobile home community on suburban high school students, Human Relations 38(7): 683-705.

Millward, C. 1995 Family networks in rural and urban settings, Family Matters 41: 10-4.

Muller, K., J. Martin. 2001 Deconstructing social exclusion, inclusionary practice in caravan parks, Parity 14(3): 11-2.

Newton, J. 2005 Microcosms, managers and permanent residence in caravan parks, Caravan Parks ... Watch This Space, Parity 18(5): 22.

Newton, J. 2006 Permanent residents in caravan parks, managers and the persistence of the social, Health Sociology Review 15(2): 221-31.

Newton, J. 2008 Emotional attachment to home and security for permanent residents in caravan parks in Melbourne, Journal of Sociology 44(3): 219-32.

Newton, J. 2014 Park Land: When Caravan is Home. Melbourne: Australian Scholarly.

Notter, M., K. MacTavish and S. Shamah. 2008 Pathways towards resilience among women in rural trailer parks, Family Relations 57(December): 613-24.

Qwah, S. E. L. 2008 Choice and Connectedness: Explaining Divorcees' Experiences Through Kinship and Self $<$ http://www.tasa.org.au/uploads/2008/12/Quah-Sharon.pdf>, accessed 11 October 2012.

Rogers, N., C. Hirte, M. Davies, A. Hume. 2009 Living in Caravan Parks in South Australia. Adelaide: Department for Families and Communities.

Sahlins, M. 2013 What Kinship Is - And Is Not. Chicago: University of Chicago Press.

Salamon, S. and K. MacTavish. 2006 Quasi-homelessness among rural trailer-park households in the United States, in (eds) P. Milbourne and P. Cloke International Perspectives on Rural Homelessness. New York: Routledge, pp. 45-62.

Schneider, D. 1968 American Kinship: A Cultural Account. Engelwood Cliffs: Prentice-Hall.

Simpson, B. 1998 Changing Families: An Ethnographic Approach to Divorce and Separation. Oxford: Berg.

Statham, J. 2011 Grandparents Providing Childcare. Briefing Paper. London and Kent: Childhood Wellbeing Research Centre, University of London, Loughborough University, University of Kent.

Stevenson, B., J. Wolfers. 2007 Marriage and Divorce: Changes in Their Driving Forces. Cambridge, MA: National Bureau of Economic Research Working Paper Series.

Stivens, M. 1985 The private life of the extended family: Family, kinship and class in a middle class suburb of Sydney, in (ed.) L. Manderson Australian Ways: Anthropological Studies of an Industrialised Society. Sydney: Allen \& Unwin, pp. 15-32.

Strathern, M. 1992 After Nature: English Kinship in the Late Twentieth Century. Cambridge: Cambridge University Press.

Wensing, E., M. Wood, D. Holloway. 2003 On the Margins? Housing Risk Among Caravan Park Residents. Sydney: Australian Housing and Urban Research Institute, UNSW-UWS Research Centre.

Zenner, D., T. Allison. 2010 Health of caravan park residents: A cross sectional study of the East Riding of Yorkshire, Health and Place 16(2): 302-14. 